\title{
UNO ULLBERG - VIIPURIN ARKKITEHTI
}

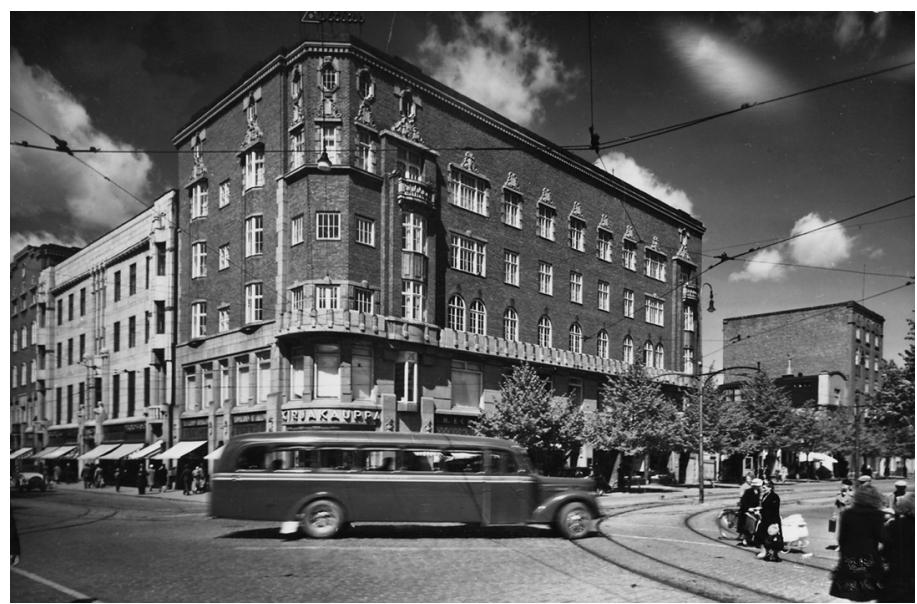

Uno Ullberg: Kiinteistö Oy Karjala Viipurissa 1912. (SRM 62/22)

Uno Ullberg (1879-1944) oli yksi sukupolvensa merkittävimpiä arkkitehteja Suomessa. Hänen työlleen on ominaista hienostunut yksilöllisyys ja samalla rakennuksen luonteva sovittaminen ympäristöönsä. Hän oli sekä uudistaja että perinteen tulkitsija, jonka taiteessa klassismi ja funktionalismi olivat luovassa jännitteessä. Ullberg oli tuottelias, mutta sodan seurauksena suurin osa hänen elämäntyötään jäi Neuvostoliiton puolelle luovutettuun Karjalaan. Siksi kai Ullbergista on tullut pikemminkin asiantuntijoiden arkkitehti kuin laajasti tunnettu mestari.

Hiljattain Ullberg on saanut julkisuutta sekä Venäjällä että Suomessa. Venäläiset ovat kunnostaneet hänen päätyönsä Viipurin taidemuseon ja piirustuskoulun vuodelta 1930 Eremitaasin filiaaliksi. Kaikkia rakennustaiteen ystäviä ilahduttaa, että mestariteos on palautettu arvoonsa. Suomalaiset tosin menettivät aloitteettomuuttaan tilaisuutensa antaa sisältöä monumentille. Ehdotin 1995, että Suomen valtio ostaisi rakennuksen suomalaisen kulttuurikeskuksen käyttöön. Varat olisi lohkaistu vaatimattomana murto-osana massiivisen Hornet-hävittäjäkaupan budjetista. Sotakoneet jyräsivät kulttuurin puolustuspolitiikan välineenä.

Viipurin taidemuseon arkkitehtuurissa funktionalistinen käytännöllisyys ja pidättyväisyys yhdistyvät ylevään klassismiin. Museon pohjakaava koostuu omintakeisesti kahdesta kiilamaisesti vastakkaisesta rakennuskappaleesta ja niitä yhdistävästä kaarevasta pilaristosta ja korkeahkosta palkista. Rakennus on pystytetty Pantsarlahden linnoituksen bastionille, josta avautuu upea näkymä Viipurinlahdelle. Vierailija hiljentyy. "Se kohosi kuin antiikin temppeli jykevältä linnakeperustaltaan", arkkitehti Otto-I. Meurman luonnehtii rakennusta.

Katutasolle taidemuseon portaita vastapäätä valmistui vuonna 1932 Ullbergin suunnittelema Ruotsalais-saksalainen seurakuntatalo, jonka julkisivun sommittelussa ja harkitussa dekoraatiossa klassismi ja modernismi käyvät vuoropuhelua. Neliömäisen ja "korkeaotsaisen" valkoisen julkisivun ikkuna-aukkojen vaihteleva kurinalaisuus antaa rakennukselle metafyysisen auran. Historistinen ele määrittää myös vuonna 1931 valmistuneen Viipurin panttilainakonttorin julkisivun suoraviivaista rationalismia. Keskustelussa postmodernismista Ullberg on haastava ja inspiroiva arkkitehti toiselta aikakaudelta.

Ullbergin tuotanto käsittää taidemuseon ja seurakuntatalon lisäksi lukuisia liike- ja asuinkerrostaloja Viipurissa, Sortavalassa, Käkisalmessa, Imatralla ja Helsingissä. Lisäksi hän suunnitteli työväen omakotitaloja, huviloita, tehtaita ja sairaaloita. Hän paneutui myös historiallisten rakennusten, kuten Viipurin pyöreän tornin, kunnostamiseen. Ullberg muutti vuonna 1936 Helsinkiin, jossa Erottajalla sijaitseva vuonna 1940 valmistunut Bensowin liiketalo on hänen funktionalistinen mestariteoksensa. 